\title{
Adverse Event Subcategory
}

National Cancer Institute

\section{Source}

National Cancer Institute. Adverse Event Subcategory. NCI Thesaurus. Code C83212.

A subdivision of adverse event data. 